\title{
Benchmarking sustainability of Indian electricity system: An indicator approach
}

\author{
Tarun Sharma, P. Balachandra* \\ Department of Management Studies, Indian Institute of Science, Bangalore 560012, India
}

\section{H I G H L I G H T S}

- Hierarchical indicator framework for sustainability assessment of electricity system.

- Prioritized and quantified 85 indicators under four dimensions of sustainability.

- Evaluated electricity system sustainability indices of India with benchmark values.

- National electricity system sustainability index (NESSI) for India is 0.48 .

- A hypothetical NESSI benchmark was developed for assessing electricity systems.

\section{A R T I C L E I N F O}

\section{Article history:}

Received 14 August 2014

Received in revised form 29 November 2014

Accepted 21 December 2014

Available online 14 January 2015

\section{Keywords:}

Electricity system

Sustainability indicators

Sustainable energy

Electricity sustainability index

\begin{abstract}
A B S T R A C T
India needs to significantly increase its electricity consumption levels, in a sustainable manner, if it has to ensure rapid economic development, a goal that remains the most potent tool for delivering adaptation capacity to its poor who will suffer the worst consequences of climate change. Resource/supply constraints faced by conventional energy sources, techno-economic constraints faced by renewable energy sources, and the bounds imposed by climate change on fossil fuel use are likely to undermine India's quest for having a robust electricity system that can effectively contribute to achieving accelerated, sustainable and inclusive economic growth. One possible way out could be transitioning into a sustainable electricity system, which is a trade-off solution having taken into account the economic, social and environmental concerns. As a first step toward understanding this transition, we contribute an indicator based hierarchical multidimensional framework as an analytical tool for sustainability assessment of electricity systems, and validate it for India's national electricity system. We evaluate Indian electricity system using this framework by comparing it with a hypothetical benchmark sustainable electrical system, which was created using best indicator values realized across national electricity systems in the world. This framework, we believe, can be used to examine the social, economic and environmental implications of the current Indian electricity system as well as setting targets for future development. The analysis with the indicator framework provides a deeper understanding of the system, identify and quantify the prevailing sustainability gaps and generate specific targets for interventions. We use this framework to compute national electricity system sustainability index (NESSI) for India.
\end{abstract}

(c) 2014 Elsevier Ltd. All rights reserved.

\section{Introduction}

India needs to significantly increase the levels of electricity production and consumption, in a sustainable manner, if it has to ensure rapid economic development - a goal that remains the most potent tool for delivering adaptation capacity to its large

\footnotetext{
* Corresponding author. Tel.: +91 80 22933268; fax: +91 8023604534.

E-mail addresses: taruniisc@mgmt.iisc.ernet.in (T. Sharma), patilb@mgmt.iisc. ernet.in (P. Balachandra).
}

number of poor who will suffer the worst consequences of extreme events induced either by human or natural systems. It is because the income poor in India are also energy poor [1]. Several other indicators suggest India has a lot to achieve to have a robust and adequate electricity system. Household electricity access level of $67.2 \%$ [2] and low per capita electricity consumption of $644 \mathrm{~kW} \mathrm{~h}$ [3] for India in 2011 compares unfavorably with two benchmark countries, USA and China, which have achieved $100 \%$ electricity access levels and have per capita consumption levels of $13,227 \mathrm{~kW}$ h and 3,298 $\mathrm{kW}$ h respectively [3]. Another aspect that 
is threatening the sustainability of India's energy system is its over dependence on fossil fuels for power generation. Greenhouse gas (GHG) emissions from the electricity system constituted $65.4 \%$ of the total 1100 million $\mathrm{tCO}_{2 \mathrm{e}}$ from energy sector in 2007 [4]. Although the annual per capita emission of $0.72 \mathrm{tCO}_{2 \mathrm{e}}$ from electricity generation is lower than the 2010 global average per capita emissions of $1.71 \mathrm{tCO}_{2 \mathrm{e}}$, considering the magnitude of its total emissions, India needs to initiate measures to reduce the emissions. Third, India has an ambitious target of achieving installed capacity to the tune of $800 \mathrm{GW}$ from the existing $200 \mathrm{GW}$ by 2032, to support and maintain the economic growth [5].

The diagnosis in the preceding paragraph provides a glimpse of conflicting and hence contentious impacts of national electricity system. The conflicts are due to the prevailing gaps in the electricity system viz. lack of access, slower growth, need for low carbon electricity, and significant infrastructure gaps. The solution lies in adopting the principles of sustainability taking into account the conflicting objectives and dimensions, as stated above, by including the aspirations of all stakeholders in planning the national electricity system of the future. Adopting this approach raises several questions. What constitutes the sustainability of national electricity system and how it is measured? Which framework is to be used to assess the sustainability of the electricity system? How India's electricity system perform on sustainability benchmark? We want to respond to these questions and use a quantitative approach for this purpose. To do this, it is important to be able to measure the sustainability status of India's electricity system development and to monitor its achievement or lack of it toward sustainability.

To respond to the above questions, we have developed an indicator based hierarchical multi-dimensional framework to evaluate, compare and benchmark the Indian electricity system for sustainability. This framework is built upon the indicator literature in this domain. Literature reports several attempts at classifying and listing of large number of indicators ranging between 93 and 372 $[6,7]$, however, the analysis using indicators, as evident from the empirical articles, is done with relatively lesser number of indicators, i.e., between 6 and 19 [8-12]. Even though there are studies discussing the attempts at classification/categorization of energy indicators into themes and sub-themes at different levels [8,13$16]$, such attempts are lacking in the context of sustainability assessment of national electricity systems. The literature has largely focused on developing theoretical and conceptual understanding of the indicator-based approaches for sustainability assessment and not on empirical validations. Given these research gaps, first, the present study contributes to bridging the methodological gap by proposing a multi-level hierarchical indicator framework with system sustainability index at the top followed by dimensions, themes, sub-themes, composite indicators and the measurable indicators as the next five levels. Next, this framework was empirically validated for the national electricity system of India by quantifying 85 indicators under different dimensions, establishing a sustainability benchmark for comparison, and developing a national electricity system sustainability index (NESSI).

\section{Literature review}

Energy must be an instrument for advancing economically viable, need oriented, self-reliant and environmentally sound development, which is now referred to as sustainable development [17]. The emphasis on sustainable development, in the context of energy, means that the focus must be on the end use of the energy and the services that energy provides for the welfare of human beings. In other words, energy is important for creating conditions of livability and economic development. In this paradigm, the emphasis is on human beings as ends in themselves and not so much as means of development. The idea is that these requirements of energy services can be satisfied by scrutinizing how energy is used, and by whom and for what purpose, that is by taking an end use approach [17]. Sustainable development of a country, in the context of electricity system, can only be achieved by responding to these questions and providing solutions to them. With sustainable development, as a process as well as an outcome, gaining importance, more studies are being carried out to gain deeper understanding of the whole gamut of issues. Sustainable development is a multidimensional concept, and needs both quantitative and qualitative assessments to derive deeper insights. Indicator-based approaches appears to be the most popular tool being employed to analyze the complexities around sustainable development. There are a number of studies which analyze sustainable development within the energy sector based on a set of measurable energy indicators for several countries and regions [8,9,18]. Researchers have also explored sustainability assessment of renewable energy systems using indicators [10,19-21]. In addition, there are attempts at developing indicators for the assessment of energy systems at a national level $[6,8,9,22]$. There is also evidence of using indicator approaches for studying the effectiveness of electricity systems by capturing the variations in the reliability levels, and price changes due to market factors and capacity constraints [23-25]. However such studies, with the exception of papers by Dimitrijevic and Salihbegovic [10] and Vithayasrichareon et al. [11], do not focus on assessment of sustainability in the context of national electricity system. Energy indicators for sustainable development [13] constructed by the International Atomic Energy Agency are widely used for assessing the energy systems [8,1416].

Organization for Economic Cooperation and Development (OECD) defines an indicator as "a parameter which provides information about the state of a phenomenon" [26]. An indicator or group of indicators is used to judge the health of the system. According to the United Nations, indicators translate physical and social science knowledge into a few numbers, which are easy to understand and facilitate decision making $[27,28]$.

Sustainability analyses of systems are successful when one can ascertain unambiguously overall superiority of the state of a system compared to alternative states. These alternative states can be the system's conditions over time intervals or alternative products or processes for the same function [29]. In such analyses, indicators or metrics that satisfactorily characterize the system can be used to obtain an aggregate index for easy decision making. The goal of sustainability analysis has two objectives - (i) to gain knowledge on the sensitivities of these indicators and their underlying control variables to overall sustainability performance, and (ii) to make continuous improvement by adjusting the control variables [29]. The indicators can assist countries in their efforts to assess the progress made in implementing sustainable development strategies in the area of energy, and can further identify specific areas in which focused measures and policies should be directed.

Measurement of sustainable development is crucial for operationalizing it. Different approaches for measuring sustainable development have led to detailed frameworks, from which indicators have been derived [30]. They help focus on what to measure, what to expect from measurement and which data to use [31]. These efforts received a major boost following the adoption of Agenda 21 at the earth summit in 1992, which specifically asks countries, international and nongovernmental organizations to develop the concept of indicators of sustainable development and to harmonize them at the national, regional and global levels [32]. Frameworks differentiate the ways in which the main dimensions of sustainable development are conceptualized, the inter linkages between these dimensions are established, and the 
rationality of the selection and aggregation of the indictors are justified [31]. Nathan and Reddy [33] and Poveda and Lipsett [34] have reviewed indicator frameworks and analyzed their merits and demerits under different contexts.

For this work, we have used the hierarchical multidimensional framework with a set of measurable energy indicators of sustainability forming the lowest hierarchy, because this framework allows for integration of mathematical modeling for decision making [16]. Such an approach to energy planning implies that future for energy is much more a matter of choice than of destiny, and that energy futures compatible with the achievement of sustainable world are within the grasp of human kind [17].

Brundtland Commission [35] defines Sustainable Development as "ability to make development sustainable - to ensure that it meets the needs of the present without compromising the ability of future generations to meet their own needs". Although the original definition does not make such a distinction, sustainable development has later become perceived as a combination of three interdependent dimensions or 'pillars' namely the: economic, environmental, and social dimensions. Globally, this description has constituted the basis for most generally accepted definitions of sustainable development [36,37].

For national electricity system to be sustainable these three sustainability aspects must be critically addressed. The national electricity system must maintain social equilibrium, it should be economically sustainable and should have least environmental footprint.

\section{Indicator-based framework for sustainability assessment}

In this section, we draw boundaries of the construct 'sustainability' as applicable in the context of national electricity system, and delimit the scope of this research. The composite of extraction and conversion technologies and processes that deliver energy services to end users is known as the energy system. National electricity system in the context of this work includes different energy sources: renewable, nuclear and fossil energy, and electrical energy pathways that convert and deliver the energy services at different physical scales within the national boundaries. Fig. 1 is a schematic representation of our conception of sustainable national electricity system. As indicated in Fig. 1, consideration of drivers for sustainability transition of national electricity system has implications for the system constituents and vice versa. Sustainable national electricity system is defined as that which contributes positively to economic and social status of the nation state without prejudicing the environment. Since the implications of desired sustainability transition for national electricity system constituents are expected to be both positive and negative, there is a possibility of operational conflicts among these constituents. Given these, a sustainable national electricity system is the one for which these conflicts are optimally resolved.

We have developed a multi-level indicator based analytical framework (Fig. 2) to model the electricity system of India. We started with the definition of "sustainable national electricity system" and finalized the dimensions constituting the first two levels in the hierarchy. We have gathered an exhaustive list of system observables (indicators) which constitutes the lowest hierarchy of the framework. The intermediate levels of themes, sub-themes and composite indicators in the hierarchy will facilitate meaningful interpretation of indicator groups. Each of the sub-themes and themes represents an issue measured collectively by the indicator group constituting them. The empirical observations under these categories, in our view are manifestations of the extent of leadership, participation and stewardship stakeholders have taken in creating and implementing policies, programs and technological innovations that contribute to the electricity system sustainability.

\subsection{Dimensions of sustainability}

Sustainable development is based on three pillars - social, economic and environmental-linked by effective governance/institutions. Balachandra [1] has discussed the interactions of energy system with social, economic and environmental dimensions of sustainable development. On the institutional front, energy planning is an instance of the need for the vital role of government institutions in ensuring that energy supply and demand decisions made by all stakeholders - producers, consumers, investors, etc., are compatible with overall goals for national sustainable development [38]. Thus in the present work we have used four dimensions

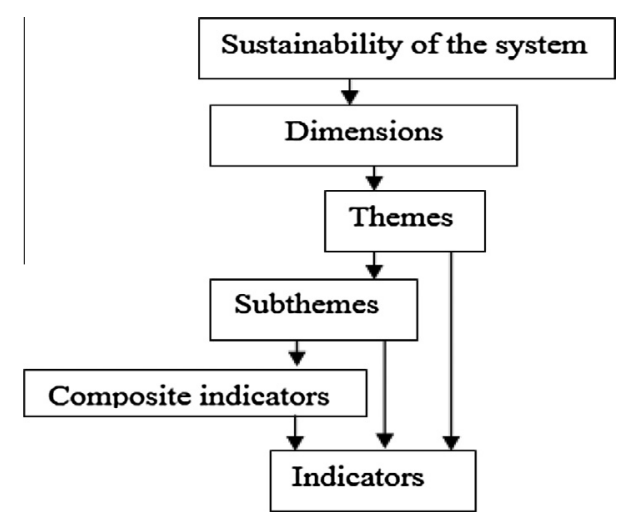

Fig. 2. Schematic of sustainability framework.

\begin{tabular}{|c|c|c|c|c|c|c|c|c|c|c|c|}
\hline \multirow{3}{*}{$\begin{array}{l}\text { Taxonomy of } \\
\text { national } \\
\text { electricity system }\end{array}$} & \multicolumn{10}{|c|}{ Drivers of sustainability transition } & \multirow{3}{*}{$\begin{array}{l}\text { Implications } \\
\text { for national } \\
\text { electricity } \\
\text { system } \\
\text { constituents }\end{array}$} \\
\hline & \multicolumn{2}{|r|}{ Social } & \multicolumn{2}{|c|}{ Economic } & \multicolumn{3}{|c|}{ Environmental } & \multicolumn{3}{|c|}{ Institutional } & \\
\hline & $\begin{array}{c}\text { Accessi } \\
\text { bility }\end{array}$ & \begin{tabular}{|l|l} 
Affordability \\
\end{tabular} & $\begin{array}{c}\text { Producti } \\
\text { on }\end{array}$ & Supply & $\begin{array}{c}\text { Amosphe } \\
\text { fe }\end{array}$ & Land & $\ldots$ & Govermance & $\begin{array}{c}\text { Fimanc } \\
\text { es }\end{array}$ & ... & \\
\hline $\begin{array}{l}\text { Renewable } \\
\text { generation }\end{array}$ & & & & & & & & & & & \\
\hline $\begin{array}{c}\text { Decentralized } \\
\text { generation }\end{array}$ & & & & & & & & & & & \\
\hline . & & & & & & & & & & & \\
\hline
\end{tabular}

Fig. 1. Schematic representation of approach to assessing sustainable national electricity system. 


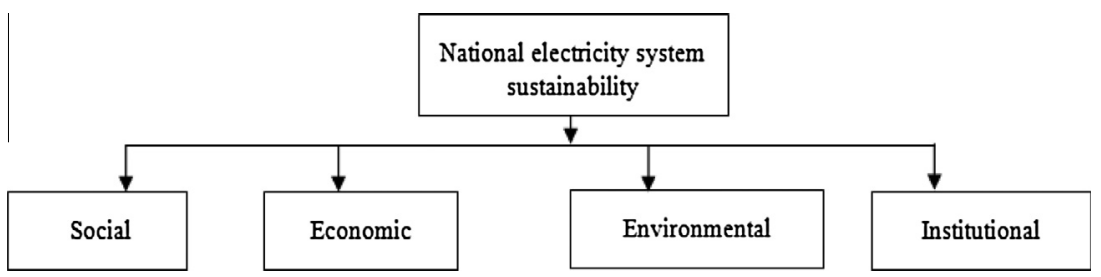

Fig. 3. Schematic representation of the framework for national electricity system sustainability.

- social, economic, environmental and institutional (Fig. 3) to assess the sustainability of the national electricity system.

- Social sustainability maps the extent of equitable, affordable and reliable access to the benefits of national electricity system for the population through societal consideration of individual and community concerns.

- Economic sustainability captures the current as well as the dynamic economic strength of the national electricity system measured through thematic constructs of production, supply, end-use and security.

- Environmental sustainability assess the conformation of evolving national electricity system to environmental standards by measuring its impact on atmosphere, land, water and possible transitions.

- Institutional sustainability measures the extent and effectiveness of governance and institutions in enabling the energy system to achieve its mandated goals on other dimensions by performing the functions of regulation, implementation, production, distribution, management, monitoring, etc.

\subsection{Themes and sub-themes of sustainability}

The dimensional constructs themselves are multi-pronged, thus, at next levels of classification of indicators, we have developed a representative set of 19 themes and 31 sub-themes under the dimensions of sustainability. These intermediate levels in the hierarchy will facilitate meaningful interpretation of indicator groups. Each of the sub-themes and themes represents an issue measured collectively by the indicator group constituting them. It is expected that multiple levels of classification increase the resolution of dimensional perspectives by providing nuanced information.

\subsubsection{Themes of social sustainability}

Fig. 4 depicts the hierarchical relations of sub-themes and themes belonging to the social dimension. There are five themes and seven sub-themes, which we believe, adequate to measure the construct social sustainability. Further, each of the sub-themes will have important representative indicators, which will provide the quantitative values to facilitate hierarchical measurement of sustainability: sub-thematic, thematic, dimensional and overall sustainability. The six themes, as discussed below, collectively enable measurement of social sustainability of electricity system.

- Accessibility: Energy is essential for all human activities and in particular, access to electricity opens up new opportunities. Universal electricity access is globally recognized as an imperative for social development. Deficits in electricity access may represent a loss in the development of human capital [39]. This theme measures the access level and the rate at which it has increased in the recent past.

- Affordability: The focus on development rather than growth necessarily means an emphasis on providing energy services required for satisfaction of basic needs of poorest sections in the society. The cost at which electricity services are provisioned is an important factor determining its usage. The aspects of cost and income affordability are accounted for by the sub-themes under this theme.

- Adequacy: Over and above physical access and cost, adequacy of electricity services is crucial. This theme accounts for the adequacy of the provisioned electricity as measured through sub-thematic constructs of availability and constancy of supply.

- Productive livelihood: National electricity system as an industry provides employment, and as a factor of production spurs enterprise development. Energy ambitions need to go beyond meeting people's 'basic survival needs' and instead be centered on energy needs in a way that help reduce poverty and improve livelihoods. Providing access to electricity for rural communities as means to encourage local economic development shows the greatest impact of electrification.

- Productivity: Electricity consumption relative to output for the economy and its sectors varies across nations. This theme measures the electricity intensity of the national economy and its sectors.

- Acceptability: The production of electricity can involve accidents and displacement of people at different steps of fuel cycle. Also a certain level of performance is expected from the electricity infrastructure. Both these have implications for social acceptability.

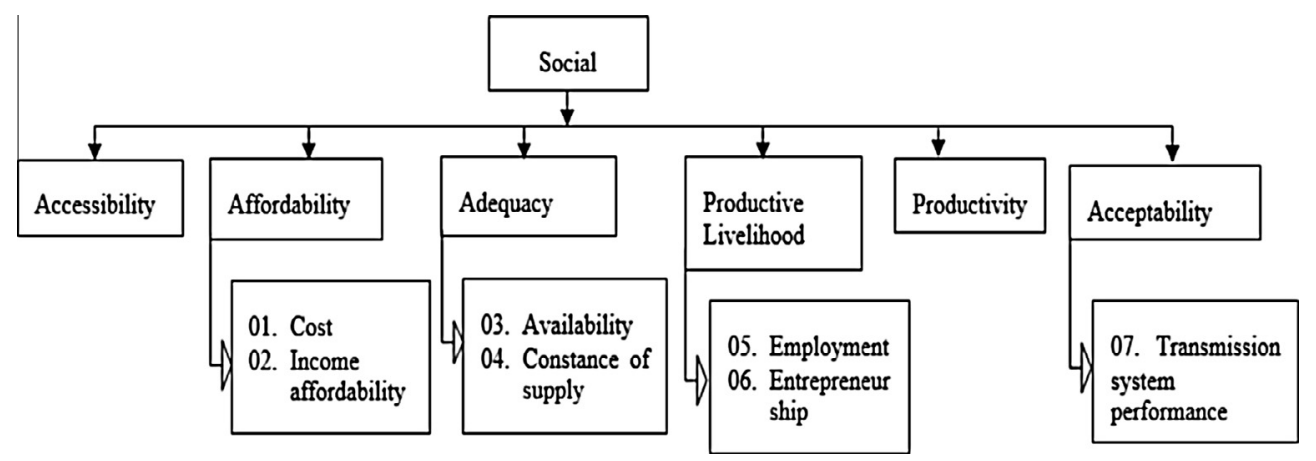

Fig. 4. Schematic representation of themes and sub-themes under the social dimension of national electricity system sustainability framework. 


\subsubsection{Sub-themes of social sustainability}

The following sub-themes under different themes represent additional classes of indicators.

- Cost: It measures the cost at which electricity is supplied. When connection charges are recovered through one time, upfront fee for new low income customers they can constitute a powerful disincentive to people who wish to obtain electricity, no matter how much they might desire the service [40]. Combination of low income households and high upfront connection cost impedes the pace of providing electricity to larger proportion of the population. The unit cost of electricity influencing post connection consumption level is equally relevant.

- Income affordability across different income groups: Indicators in this sub-theme measure the extent to which the variation in electricity consumption across different income/expenditure groups is attributable to the income.

- Availability: It measures electricity available for supply on a per capita basis, and the rate at which it has increased in the last five years.

- Constancy of supply: It captures the peak shortage levels and the overall deficit in electricity supply.

- Employment: It measures the direct, indirect and induced employment attributable to electricity system.

- Entrepreneurship: It measures the instances of micro and small scale rural enterprises enabled by electricity supply.

- Transmission system performance: This is constituted by availability, security of supply and quality. There is a statutory obligation on the grid operating authority to maintain the voltage and frequency parameters within a set range to ensure proper operation of grid.

\subsubsection{Themes of economic sustainability}

Fig. 5 depicts the hierarchical relations of sub-themes and themes belonging to the economic dimension of sustainability.

- Production: This theme constitutes indicators used to quantify sustainability of electricity production measured through subthemes on resource stock, technology deployment and decentralization.

- Supply: Electricity transmission and distribution systems provide the critical link for the supply of electricity from generators to electricity consumers. This theme accounts for supply efficiency and financial viability of electricity transmission and distribution.

- End use: Indicators in this theme measure the level of electricity consumption in different sector of the economy and its trend in the household sector.

- Cost: It is an aggregate of average tariff and levelized cost of electricity generation by selected technologies. For technolo- gies, it captures the extent of technology transfer, maturation and national capacity.

- Security: It addresses the energy security concerns of the country as captured through short term reliability and long term continuity of electricity supply.

\subsubsection{Sub-themes of economic sustainability}

- Resource stock: Fossil fuel resource (coal, oil and natural gas) endowments will influence the nature and direction of change in the national electricity system. Availability and geographic distribution of the resource dictates the energy trade patterns. This theme is constituted by the variables related to natural resource stocks and the rate of their extraction.

- Generation: It consists of two indicators, the first one indicates the rate at which generation capacity is increasing, and the second one, utilization of the existing capacity.

- Technology deployment: Technology choices are important determinants of consumption levels and consumption efficiencies. This sub-theme includes the aggregate technology related indicators. The underlying assumption is that any technology interventions will directly impact these indicators.

- Decentralization: There are a number of technological tasks which derive from the country's intention to change from present pattern of growth to an alternative inequality-reducing pattern of growth [8]. This generic observation has a strong resonance in national electricity system. There is substantial evidence to support the positive correlation between access to electricity and poverty alleviation. Simultaneously, with the conventional centralized production system losing its traction as the only electricity generation and supply augmentation paradigm, there is an increasing consensus on the importance of distributed stand-alone or micro grid systems. For sparsely populated and remote areas, mini-grid and stand-alone renewable energy systems can be cost-effective alternatives to grid-based or diesel-based systems. It is in this sense that decentralization is widely acknowledged to make the electricity system more sustainable. Indicators in this sub-theme measure the extent of decentralization in the national electricity system.

- Supply efficiency: A substantial amount of electricity is lost during transmission and distribution. This sub-theme measures the efficiency of electricity transmission and distribution network.

- Financial viability of distribution: It captures the financial viability of transmission and distribution as a difference of aggregate cost and aggregate tariff.

- Sectoral consumption: It captures the distribution of electricity amongst the economic sectors of the country.

- Non-commercial use: It takes into account the magnitude of the electricity consumption in households and how it has changed in the recent past.

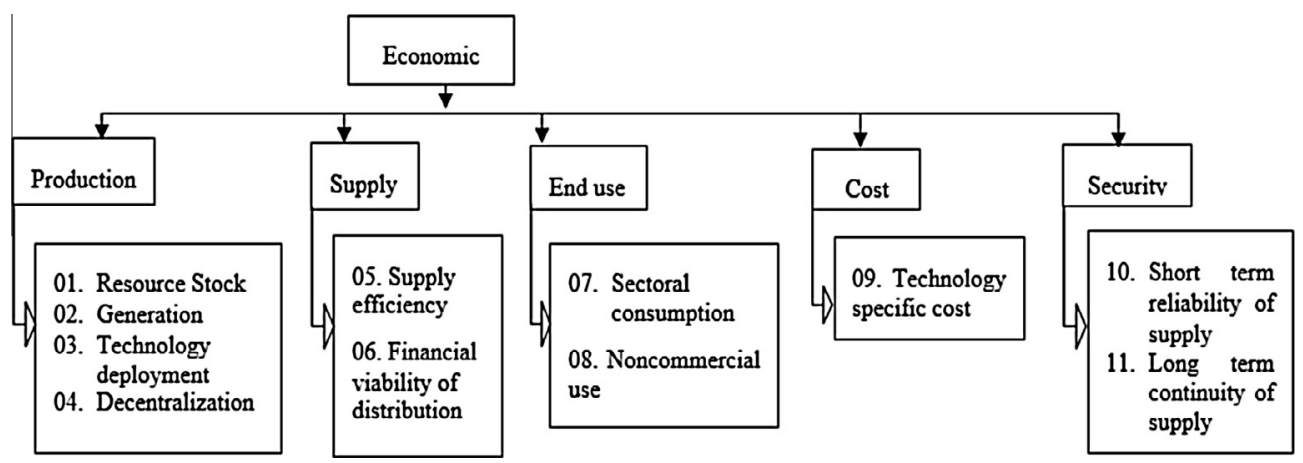

Fig. 5. Schematic representation of themes and sub-themes under the economic dimension of national electricity system sustainability framework. 
- Technology specific costs: Technologies follow a maturation cycle before attaining a critical mass rendering them competitive and hence financially viable. This sub-theme encapsulates the costs for candidate technologies.

- Short term reliability of supply: Indicators in this sub-theme address the short term issues of insufficient generation and network capacity to meet demand, arising from inefficient plants, poor maintenance, or other factors such as extreme weather events.

- Long term continuity of supply: Indicators in this sub-theme address the long terms issues such as the availability of fuel sources like coal and gas, diversified portfolio of different technologies and fuel types, and resources that can mitigate energy security risks.

\subsubsection{Themes of environmental sustainability}

Fig. 6 depicts the hierarchical relations of sub-themes and themes belonging to the Environmental dimension.

- Atmosphere: It measures the impact of electricity system on the atmosphere as measured through its contributions to emissions of greenhouse gases and other pollutants.

- Land: It measures the impact of electricity system on land use, soil quality, forest, solid waste generation and the status of management of such waste.

- Water: Indicators in this sub-theme measure the impact of electricity system on the water resource. Electricity system is a competing sector for water use. Globally, electricity generation accounts for a large and potentially growing share in water demand. Hence evolution of generation mix is important for future water demands from the sector [41].

- Environmental transition: In electricity supply chains, power generation is the major contributor of emissions associated with climate change. This construct encapsulates the current status of carbon intensity of power generation, and the rate at which this intensity has improved in recent years.

\subsubsection{Sub-themes of environmental sustainability}

- Climate change: Indicators in this sub-theme account for the greenhouse gas emissions, which are responsible for climate change through several processes related to electricity system.

- Air quality: Indicators in this sub-theme measure the air pollution intensities of electricity system.

- Land use: It takes into account the direct land use associated with electricity generation technologies.

- Soil quality: It accounts for the land contamination due to electricity generation.

- Forest: Deforestation is a serious environmental issue, with global implications manifested through its impact on climate change. This sub-theme measures the rate of deforestation attributed to the electricity system.

- Solid waste generation and management: Indicators in this subtheme measure how much solid waste is generated by the electricity system and the extent of its disposal.

- Water use: It takes into account the water consumption by electricity generating technologies.

- Water quality: It accounts for contaminant discharges like mercury, thermal discharge etc., in the form of liquid effluents from electricity system.

- Low carbon transition: It measures the extent to which electricity generation is low carbon and the rate at which low carbon electricity generation status is improving.

- Zero carbon transition: It captures the augmentation rate of zero carbon technologies for electricity generation.

\subsubsection{Themes of institutional sustainability}

Fig. 7 shows the hierarchical relations of sub-themes and themes belonging to the Institutional dimension.

- Energy sector governance: This theme captures the stakeholder perceptions and outlook of the government on national electricity systems. This theme is a recognition of emphasis on the role of government in the development of national electricity system.

- Competition and markets: It captures the nature of transactions amongst different entities (central government, state government and non-government entities) which are active in national electricity system by measuring ease of doing business, status of open access and effectiveness of business regulatory environment.

- Finance: It measures ease of access to finance for energy project financing.

- Access to information: It accounts for periodic publication of official energy planning documents and/or statistics and the extent of coverage in terms of non-negligible impacts associated with the electricity system.

\subsubsection{Sub-themes of institutional sustainability}

- Policy: It accounts for presence, quality and extent of implementation of a coherent government policy on the national electricity system.

- Institutions: Execution of policy mandate requires establishment of institutions. This sub-theme measures the adequacy and effectiveness of the established institutions.

- Legislation: It accounts for the laws promulgated by the government to regulate, authorize, grant, declare or control the national electricity system.

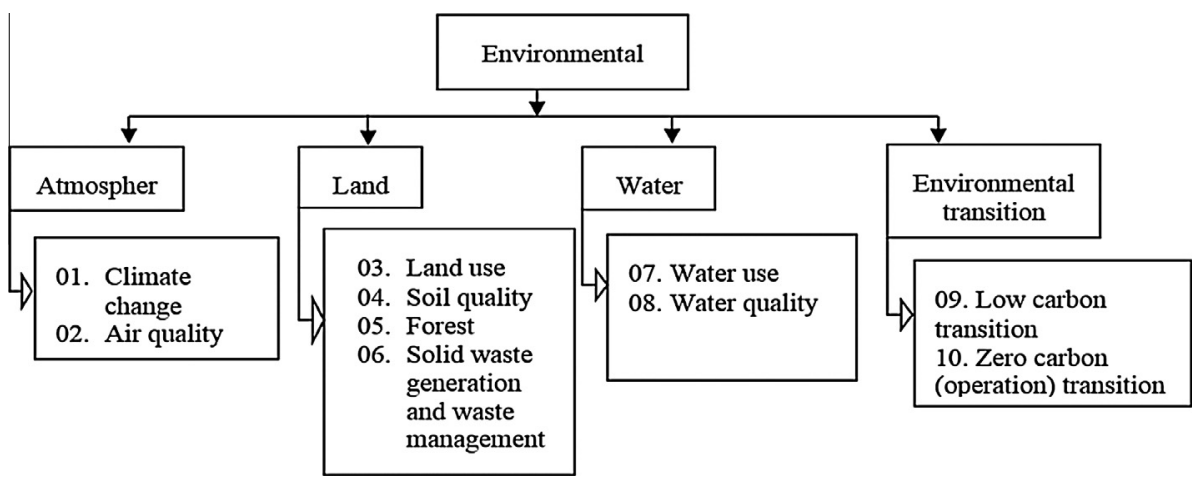

Fig. 6. Schematic representation of themes and sub-themes under the environmental dimension of national electricity system sustainability framework. 


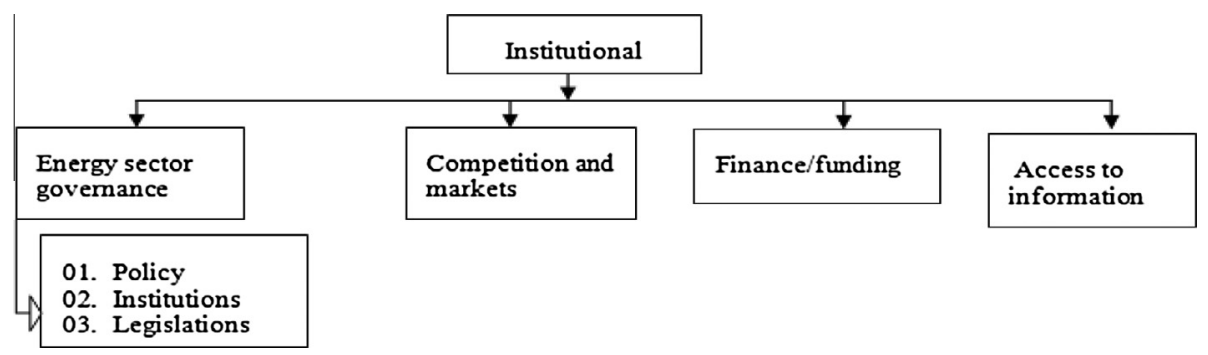

Fig. 7. Schematic representation of themes and sub-themes under the institutional dimension of national electricity system sustainability framework.

\subsection{Indicators of sustainable national electricity system}

As explained above, the hierarchal indicator framework has dimensions at the top level, themes at second level, sub-themes in the third level and composite indicators at fourth level. Finally, the actual indicators of measurement under each sub-theme form the fifth level of the hierarchical framework. Martchamadol and Kumar [7] have compiled lists of indicators as used in fifteen different energy indicator initiatives under four dimensions - economic, social, environmental and institutional having 68, 7, 7 and 11 indicators respectively. Addressing similar concerns, Sovacool and Mukherjee [6] have used mixed methods approach including "modified Delphi method", quantitative survey, workshops and literature review in that order to propose a classification scheme for 320 simple and 52 complex indicators.

We observe, while the theoretical and conceptual articles in this field of scientific investigation, lists a large number of indicators, for example, 372 by Sovacool and Mukherjee, 93 by Martchamadol and Kumar [6,7], the analysis using indicators, as evident from the empirical articles, is done with relatively lesser number of indicators, i.e., 9 by Angelis et al.; 6 by Schlor et al.; 9 by Dimitrijevic and Salihbegovic; 18 by Vithayasrichareon et al.; and 19 by Selvakkumaran and Limmeechokchai [8-12]. In this paper, we have prioritized a total of 119 indicators through a rigorous literature review, intensive brain storming, and logical assessments.

The choice of indicators compiled for a country's sustainability assessment typically depends on the national circumstances and priorities, sustainability and development criteria, prioritized objectives as well as data availability (Table 1). Selection of hierarchy, constructs and variables is invariably a consultative and iterative process. Tables $2-5$ contain the finalized hierarchical constructs and system observable indicators, quantified and used for analysis in this paper, after multiple top to bottom rounds of consultative iterations and subsequent filtering enforced by data availability. This work is a contribution in terms of holistic consideration of different pertinent constructs associated with electricity, and to our knowledge, is one of the very few attempts at quantification of indicators achieved through synthesis of literature, brain storming and expert consultation.

\section{Benchmarking sustainability of national electricity system - An approach}

Benchmarks provide a context to stand alone observed values of the indicators, to seed any debate and contention about whether the achievement or lack of it in the indicator values is desirable, undesirable or satisfactory. Benchmarking serves to set expectations. For this work, we have developed a benchmark indicatorbase using upper and lower threshold values of indicators. The indicator values for the national electricity system are evaluated (normalized) against two hypothetical national electricity systems constructed using these threshold values. The benchmarks are
Table 1

Assessment of indicators.

\begin{tabular}{llcc}
\hline & $\begin{array}{l}\text { Indicators } \\
\text { with data }\end{array}$ & $\begin{array}{l}\text { Indicators } \\
\text { with no data }\end{array}$ & $\begin{array}{l}\text { Total } \\
\text { indicators }\end{array}$ \\
\hline Social & 20 & 9 & 29 \\
Economic & 38 & 8 & 46 \\
Environmental & 14 & 11 & 25 \\
Institutional & 13 & 6 & 19 \\
Total indicators & 85 & 34 & 119 \\
\hline
\end{tabular}

taken from the best and the worst indicator values realized across national electricity systems in the world.

For some indicators, the distinction between their status of being good or bad is straight forward, while for others the status needs to be considered in the context of the development choices made. The indicators for which a higher value is favorable are referred to as benefit indicators and the indicators for which the vice versa holds good are referred to as cost indicators. When working with indicators there are issues related to benchmarking and aggregation. In the following sections, we elaborate on the threshold indicator values, the concept of developing two hypothetical electricity systems and their relevance as benchmarks.

\subsection{Developing the benchmark - Threshold indicator values}

An important observation emerging out of the literature review was that there is no standard baseline or benchmark for electricity sustainability indicators, to which we can compare the observed indicator values to get an objective measure of the system performance. Vithayasrichareon et al., in their work with indicators, have used a cross country comparison for ASEAN countries [11]. Schlor et al., in their paper, have used normative sustainability goals as defined by the German government to benchmark the observed indicator values [9]. Martchamadol and Kumar have proposed an algorithm for aggregation of indicators, with standardization of present observed indicator values relative to the observed past and simulated future time series indicator values for the same system [7].

When deriving benchmarks through cross country comparisons, the group defining criteria establishing the peer set could be, for example, geographical location, size, development status, population etc. We have compiled a country-wise database for the prioritized indicators after applying several peer group criteria and removing the outliers. From this database, for each indicator, lower and upper threshold values are derived. These threshold values, serve as the benchmark by providing a frame of reference to stand alone observations of Indian electricity system. The set of all upper threshold indicator values can be viewed as a hypothetical best performing sustainable electricity system. Similarly, the set of all lower threshold indicator values can be viewed as the worst performing hypothetical electricity system on sustainability scale. 
Table 2

Indicators of national electricity system - social sustainability.

\begin{tabular}{|c|c|c|c|c|c|c|c|c|c|}
\hline \multirow[t]{2}{*}{ Themes } & \multirow[t]{2}{*}{ Sub-theme } & \multirow[t]{2}{*}{ Indicator } & \multirow[t]{2}{*}{ Unit } & \multirow{2}{*}{$\begin{array}{l}\text { Indicator } \\
\text { value for } \\
\text { India }\end{array}$} & \multicolumn{2}{|c|}{ Threshold } & \multicolumn{2}{|c|}{ Threshold countries } & \multirow{2}{*}{$\begin{array}{l}\text { Normalized } \\
\text { value }\end{array}$} \\
\hline & & & & & Upper & Lower & Upper & Lower & \\
\hline \multirow[t]{4}{*}{$\begin{array}{l}\text { Accessibility/ } \\
\text { connectivity }\end{array}$} & & $\begin{array}{l}\text { Electrification rate (access to total } \\
\text { population in } 2010 \text { relative to } 2000 \\
\text { measured as \%) }\end{array}$ & $\%$ & 20.39 & 39.43 & 5.26 & Morocco & Bhutan & 0.44 \\
\hline & & Urban household electricity access & $\%$ & 92.7 & 100 & 58.2 & $\begin{array}{l}\text { Albania, } \\
\text { Australia }\end{array}$ & Kenya & 0.83 \\
\hline & & Rural household electricity access & $\%$ & 55.3 & 100 & 4.8 & $\begin{array}{l}\text { Albania, } \\
\text { Australia }\end{array}$ & Ethiopia & 0.53 \\
\hline & & $\%$ age of villages electrified & $\%$ & 94.47 & 100 & 4.8 & $\begin{array}{l}\text { many } \\
\text { countries }\end{array}$ & Ethiopia & 0.94 \\
\hline \multirow[t]{4}{*}{ Affordability } & Cost & $\begin{array}{l}\text { Cost of connection/MPCE for rural areas } \\
(-)\end{array}$ & Ratio & 2.85 & 4.22 & 0.2 & Ethiopia & Thailand & 0.34 \\
\hline & & Average tariff $(-)$ & $\begin{array}{l}\text { US Cents/ } \\
\mathrm{kWh}\end{array}$ & 5.95 & 20.71 & 4.55 & Argentina & Bhutan & 0.91 \\
\hline & $\begin{array}{l}\text { Income } \\
\text { affordability }\end{array}$ & $\begin{array}{l}\text { Household electricity consumption to } \\
\text { Lifeline consumption level }\end{array}$ & ratio & 0.23 & 1 & 0.131 & & Nepal & 0.12 \\
\hline & $\begin{array}{l}\text { across different } \\
\text { income groups }\end{array}$ & $\begin{array}{l}\text { Average household final consumption } \\
\text { expenditure/Cost of lifeline } \\
\text { consumption }\end{array}$ & Ratio & 11.37 & 349.9 & 1.08 & $\begin{array}{l}\text { United } \\
\text { States }\end{array}$ & $\begin{array}{l}\text { Democratic } \\
\text { republic of } \\
\text { Congo }\end{array}$ & 0.03 \\
\hline \multirow[t]{4}{*}{ Adequacy } & Availability & $\begin{array}{l}\text { Net electricity available for supply per } \\
\text { capita }\end{array}$ & $\mathrm{kWh}$ & 653.91 & 7080 & 248.45 & Germany & Angola & 0.06 \\
\hline & & $\begin{array}{l}\text { Rate of increase of electricity available } \\
\text { for supply ( } 2011 \text { to } 2001 \text { ratio) }\end{array}$ & Ratio & 1.74 & 4.52 & 0.89 & Cambodia & $\begin{array}{l}\text { United } \\
\text { Kingdom }\end{array}$ & 0.23 \\
\hline & Constancy of & Peak shortage $(-)$ & $\%$ & 9.00 & 25 & 0 & & & 0.64 \\
\hline & supply & $\begin{array}{l}\text { Reliability ([1-(Estimated unsupplied } \\
\text { energy/total energy that would have } \\
\text { been supplied by the transmission } \\
\text { system)]*100)) }\end{array}$ & $\%$ & 91.3 & 100 & 80 & & & 0.565 \\
\hline \multirow[t]{4}{*}{ Productivity } & & Economic productivity (GDP/KWh) & $\begin{array}{l}\text { US \$ PPP/ } \\
\mathrm{kW} \mathrm{h}\end{array}$ & 3.8 & 18.5 & 2.1 & Ethiopia & Canada & 0.104 \\
\hline & & Electricity Intensity in Industrial sector & US $\$ / \mathrm{kW} \mathrm{h}$ & 0.012 & 0.0422 & 0.008 & Japan & South Africa & 0.117 \\
\hline & & Electricity Intensity in Services sector & US $\$ / \mathrm{kW} \mathrm{h}$ & 0.134 & 0.157 & 0.033 & Japan & South Korea & 0.815 \\
\hline & & $\begin{array}{l}\text { Electricity Intensity in agricultural } \\
\text { sector }\end{array}$ & US $\$ / \mathrm{kW} \mathrm{h}$ & 0.021 & 0.67 & 0.012 & Japan & South Africa & 0.013 \\
\hline \multirow[t]{3}{*}{ Acceptability } & & Air Pollution - PM2.5 Exceedance ${ }^{\mathrm{a}}$ & & 0 & 100 & 0 & Vanuatu & India & 0 \\
\hline & & Security & $\begin{array}{l}\text { Reliability } \\
\text { of supply }\end{array}$ & 0.913 & 1 & 0.8 & & & 0.565 \\
\hline & & $\begin{array}{l}\text { Quality (Outages are accounted for } \\
\text { under constancy of supply) (-) }\end{array}$ & $\begin{array}{l}\text { Frequency } \\
\text { excursion }^{\mathrm{c}}\end{array}$ & 10 & 30 & 0 & & & 0.67 \\
\hline
\end{tabular}

a http://epi.yale.edu/epi/country-profile/india.

b (1-Proportion of energy deficit).

c \% of time frequency was below $49.7 \mathrm{~Hz}$ or above $50.2 \mathrm{~Hz}$.

\subsection{Developing the sustainability indices}

In real life situations, indicator values have different measurement units (access level in percentage, electricity in $\mathrm{kW} \mathrm{h}$, etc.). For developing composite indices, it is essential to transform them to the same scale. Thus, for each indicator included in the analysis, standardized indicator value is estimated using the observed and the sustainability threshold values. As a consequence, the range defined by the sustainability threshold values is transformed to a range of 0 and 1 , and so is the observed value to a value between 0 and 1 . The equation ${ }^{1}$ used is:

\section{Standardized indicator value}

Actual value - Minimum threshold value

\section{$=\frac{\text { Maximum threshold value }- \text { Minumum threshold value }}{}$}

The association of the hierarchical structure formed by the themes, sub-themes and indicators with a weighting (differential or equal weights) system allows estimation of the relative contri-

\footnotetext{
${ }^{1}$ We have made a distinction between a cost indicator and a benefit indicator in Section 4 . This equation holds for benefit indicators, where an indicator value closer to the maximum threshold value manifests as higher effective indicator value. For cost indicators the normalized indicator value obtained in equation is subtracted from 1 to get the effective indicator value.
}

butions of each of these components to overall index value. To this end, the differential weights can be derived by computations on time series data of indicators [7] or by expert elucidation through surveys [42] or perceptional/preferential (by experts) weight assignment $[43,44]$. For aggregation at different levels as depicted in Fig. 2, we have assigned equal weights to constituent contributions.

\section{India's electricity system - A brief profile}

The Indian electricity system is divided into two major grids, the integrated grid consisting of Northern, Eastern, Western, and North-Eastern regional grids, and the Southern Grid. Each grid covers several states. About $84.6 \%$ of the capacity is owned by the utilities. $^{2}$ The total installed capacity of power utilities as on 31.03.2013 was 223,344 MW [45]. The generation is predominantly dependent on thermal (coal and natural gas), constituting $66 \%$ of the total installed capacity. This is followed by $16.49 \%$ of hydro power. Though the current share of nuclear energy is only $2.02 \%$, the compound annual growth rate of $5.96 \%$ since 1971 is second only to

\footnotetext{
${ }^{2}$ Utilities are electric power companies that engage in generation, transmission and distribution of electricity for sale.
} 
Table 3

Indicators of national electricity system - economic sustainability.

\begin{tabular}{|c|c|c|c|c|c|c|c|c|c|c|}
\hline \multirow[t]{2}{*}{ Theme } & \multirow[t]{2}{*}{ Sub-theme } & \multirow{2}{*}{$\begin{array}{l}\text { Composite } \\
\text { indicator }\end{array}$} & \multirow[t]{2}{*}{ Indicator } & \multirow[t]{2}{*}{ Unit } & \multirow{2}{*}{$\begin{array}{l}\text { Indicator } \\
\text { value } \\
\text { for India }\end{array}$} & \multicolumn{2}{|c|}{ Thresholds } & \multicolumn{2}{|c|}{ Threshold countries } & \multirow{2}{*}{$\begin{array}{l}\text { Normalized } \\
\text { value }\end{array}$} \\
\hline & & & & & & Upper & Lower & Upper & Lower & \\
\hline \multirow[t]{19}{*}{ Production } & \multirow[t]{6}{*}{ Resource } & \multirow[t]{3}{*}{ Endowment } & \multirow{3}{*}{$\begin{array}{l}\text { Reserves to production ratio for } \\
\text { coal, oil and natural gas }\end{array}$} & Years of coal & 100 & 443 & 4 & Russia & Vietnam & 0.22 \\
\hline & & & & Years of oil & 17.5 & 88.7 & 2.7 & Kuwait & Thailand & 0.17 \\
\hline & & & & Years of gas & 33.1 & 80.1 & 5.9 & Saudi Arabia & Denmark & 0.37 \\
\hline & & \multirow[t]{6}{*}{ Utilization } & \multirow{3}{*}{$\begin{array}{l}\text { Production to consumption } \\
\text { ratio }\end{array}$} & Ratio for coal & 0.767 & 4.09 & 0.01 & Australia & South Korea & 0.19 \\
\hline & & & & Ratio for oil & 0.244 & 10.29 & 0.08 & Qatar & Italy & 0.02 \\
\hline & & & & Ratio for gas & 1.35 & 8.78 & 0.03 & Italy & Norway & 0.15 \\
\hline & \multirow[t]{2}{*}{ Generation } & & Capacity addition (2005-2010) & $\%$ change & 41.04 & 83.31 & 4.34 & China & Russia & 0.46 \\
\hline & & & Capacity utilization & Hours & 4612.91 & 6346 & 1322.5 & Bangladesh & Lithuania & 0.66 \\
\hline & \multirow[t]{9}{*}{$\begin{array}{l}\text { Technology } \\
\text { Deployment }\end{array}$} & & $\begin{array}{l}\text { Extent of grid generation } \\
\text { portfolio diversification }\end{array}$ & $\begin{array}{l}\text { Shannon } \\
\text { Weiner index }\end{array}$ & 0.59 & 0.92 & 0.39 & Spain & China & 0.38 \\
\hline & & \multirow[t]{4}{*}{ Renewability } & $\begin{array}{l}\text { Share of renewable capacity in } \\
\text { total capacity amongst utilities }\end{array}$ & $\%$ & 27.4 & 78.65 & 1.98 & Brazil & South Africa & 0.33 \\
\hline & & & $\begin{array}{l}\text { Renewable electricity (\% in total } \\
\text { electricity output) amongst } \\
\text { utilities }\end{array}$ & $\%$ & 14.211 & 84.78 & 0.963 & Brazil & South Africa & 0.16 \\
\hline & & & $\begin{array}{l}\text { Realization of renewable } \\
\text { electricity generation potential }\end{array}$ & $\%$ & 22.33 & 31.17 & 0.58 & Spain & Norway & 0.71 \\
\hline & & & $\begin{array}{l}\text { Rate of increase of renewable } \\
\text { generation capacity (2010/ } \\
2000)\end{array}$ & Ratio & 2.1 & 11 & 0.77 & Hungary & Rwanda & 0.13 \\
\hline & & \multirow[t]{9}{*}{ Modernity } & $\begin{array}{l}\text { Hydroelectric capacity in the } \\
\text { year } 2010 \text { compared to } 2000\end{array}$ & Ratio & 1.61 & 7.41 & 0.78 & Myanmar & Dominica & 0.13 \\
\hline & & & $\begin{array}{l}\text { Fossil electricity generation } \\
\text { capacity in the year } 2010 \\
\text { relative to } 2000\end{array}$ & Ratio & 1.78 & 6.6 & 0.5 & Norway & Moldova & 0.21 \\
\hline & & & $\begin{array}{l}\text { Nuclear electricity capacity in } \\
2010 \text { to } 2000\end{array}$ & Ratio & 1.67 & 4.92 & 0.5 & China & Bulgaria & 0.26 \\
\hline & & & $\begin{array}{l}\text { Renewable (excluding hydro) } \\
\text { electricity capacity in year } 2010 \\
\text { compared to } 2000\end{array}$ & Ratio & 9.5 & 78 & 1.61 & Poland & Thailand & 0.10 \\
\hline & \multirow[t]{5}{*}{$\begin{array}{l}\text { Extent of } \\
\text { Decentralization }\end{array}$} & & $\begin{array}{l}\text { Relative number of households } \\
\text { connected to decentralized } \\
\text { generation }\end{array}$ & Ratio & 0.018 & 0.22 & 0 & Nepal & Bangladesh & 0.08 \\
\hline & & & Remote village electrification & $\%$ & 86.66 & 100 & 0 & & & 0.87 \\
\hline \multirow[t]{3}{*}{ Supply } & & & $\begin{array}{l}\text { Transmission and distribution } \\
\text { losses }(-)\end{array}$ & $\%$ & 24.95 & 36.45 & 6.19 & Moldova & China & 0.38 \\
\hline & & & $\begin{array}{l}\text { Average thermal efficiency of } \\
\text { power plants }\end{array}$ & $\%$ & 28.71 & 40.49 & 19.96 & Brazil & Angola & 0.43 \\
\hline & & & $\begin{array}{l}\text { Rate of change of supply } \\
\text { efficiency }\end{array}$ & $\%$ & 19.34 & 31.38 & 16 & Angola & Moldova & 0.22 \\
\hline \multirow[t]{7}{*}{ End use } & \multirow{5}{*}{$\begin{array}{l}\text { Sectoral } \\
\text { consumption of } \\
\text { electricity }\end{array}$} & & Commercial and public services & $\%$ & 8.33 & 34.98 & 5.56 & $\begin{array}{l}\text { United } \\
\text { States }\end{array}$ & China & 0.09 \\
\hline & & & Residential & $\%$ & 21.79 & 56.9 & 13.64 & Saudi Arabia & Korea & 0.19 \\
\hline & & & Agriculture/Forestry & $\%$ & 17.95 & 17.95 & 0.09 & India & Japan & 1.00 \\
\hline & & & Transport & $\%$ & 1.81 & 11.74 & 0.2 & Russia & United States & 0.14 \\
\hline & & & Industry & $\%$ & 44.87 & 68.47 & 12.4 & China & Saudi Arabia & 0.58 \\
\hline & \multirow[t]{2}{*}{ Noncommercial use } & & Annual household consumption & $\mathrm{kWh}$ & 778 & 5571 & 509 & Japan & Chad & 0.05 \\
\hline & & & $\begin{array}{l}\text { Rate of increase of annual } \\
\text { household consumption }\end{array}$ & $\%$ & 12.27 & 86.57 & 2.51 & China & Nepal & 0.12 \\
\hline Cost & $\begin{array}{l}\text { Technology specific } \\
\text { cost }\end{array}$ & & Aggregated tariff $(-)$ & $\begin{array}{l}\text { US cents/ } \\
\text { KWh }\end{array}$ & 5.95 & 20.47 & 4.55 & Argentina & Bhutan & 0.91 \\
\hline & & & Small hydro power (-) & US\$ & 0.0480 & 0.068 & 0.031 & $\begin{array}{l}\text { OECD North } \\
\text { America }\end{array}$ & China & 0.56 \\
\hline & & & On shore wind power $(-)$ & US\$ & 0.0750 & 0.12 & 0.075 & Other Asia & India & 1.00 \\
\hline & & & Biomass power $(-)$ & US\$ & 0.052 & 0.077 & 0.050 & $\begin{array}{l}\text { OECD North } \\
\text { America }\end{array}$ & Africa & 0.92 \\
\hline & & & Solar PV (-) & US\$ & 0.236 & 0.310 & 0.145 & Other Asia & Latin America & 0.45 \\
\hline & & & Hydro large (-) & US\$ & 0.040 & 0.034 & 0.095 & China & $\begin{array}{l}\text { Eastern Europe and } \\
\text { Central Asia }\end{array}$ & 0.89 \\
\hline Security & $\begin{array}{l}\text { Short term } \\
\text { Reliability of supply }\end{array}$ & & Reserve margin & $\%$ & 28 & 54 & 8 & Philippines & Korea & 0.43 \\
\hline & $\begin{array}{l}\text { Long term } \\
\text { Continuity of supply }\end{array}$ & & $\begin{array}{l}\text { Reliance on imported fuels for } \\
\text { electricity generation }(-)\end{array}$ & & 2.66 & 3 & 1.63 & Vietnam & Thailand & 0.25 \\
\hline & & & Fuel diversity for grid & $\begin{array}{l}\text { Shannon- } \\
\text { Weiner index }\end{array}$ & 0.52 & 0.99 & 0.19 & Armenia & Iran & 0.42 \\
\hline
\end{tabular}

the growth rate of thermal generating capacity, which for the same duration is pegged at $7.36 \%$. Out of gross electricity generation of 963 TW h in 2012, about 817 TW h was thermal. The constitution of generating capacity explains the high $\mathrm{CO}_{2}$ intensity of electricity generation of $0.83 \mathrm{~kg} / \mathrm{kWh}$ [46].

Grid interactive renewable power as on 31.12.2013 was $28,067 \mathrm{MW}$, which is a $12.66 \%$ increase from the last year [45]. 
Table 4

Indicators of national electricity system - environmental sustainability.

\begin{tabular}{|c|c|c|c|c|c|c|c|c|c|}
\hline \multirow[t]{2}{*}{ Theme } & \multirow[t]{2}{*}{ Subtheme } & \multirow[t]{2}{*}{ Indicator } & \multirow[t]{2}{*}{ Unit } & \multirow{2}{*}{$\begin{array}{l}\text { Indicator } \\
\text { value for } \\
\text { India }\end{array}$} & \multicolumn{2}{|c|}{ Thresholds } & \multicolumn{2}{|c|}{ Threshold countries } & \multirow{2}{*}{$\begin{array}{l}\text { Normalized } \\
\text { value }\end{array}$} \\
\hline & & & & & Upper & Lower & Upper & Lower & \\
\hline \multirow[t]{7}{*}{ Atmosphere } & \multirow[t]{3}{*}{$\begin{array}{l}\text { Climate } \\
\text { change }\end{array}$} & $\mathrm{CO}_{2}$ intensity of electricity production (-) & $\begin{array}{l}\mathrm{kg} / \\
\mathrm{kW} h\end{array}$ & 0.83 & 1.2 & 0.24 & Estonia & Ghana & 0.39 \\
\hline & & $\mathrm{CO}_{2}$ emissions from electricity generation per unit GDP (-) & $\begin{array}{l}\mathrm{kg} / \\
\text { Current } \\
\text { US\$ }\end{array}$ & 0.514 & 0.97 & 0.077 & Kosovo & $\begin{array}{l}\text { Kenya/United } \\
\text { Kingdom }\end{array}$ & 0.51 \\
\hline & & $\begin{array}{l}\text { Electricity production from renewable sources, including } \\
\text { hydroelectric }\end{array}$ & $\%$ & 14.21 & 84.78 & 0 & Brazil & Botswana/UAE & 0.17 \\
\hline & \multirow[t]{4}{*}{ Air quality } & Sulphur oxides $(-)$ & $\mathrm{g} / \mathrm{kW} \mathrm{h}$ & 4 & 5.96 & 0.04 & Estonia & Austria & 0.33 \\
\hline & & Particulates (PM 10) (-) & $\begin{array}{l}\mathrm{mg} / \\
\text { cubic } \\
\text { meters }\end{array}$ & 51.97 & 114.96 & 5.86 & Bangladesh & $\begin{array}{l}\text { Equatorial } \\
\text { Guinea }\end{array}$ & 0.58 \\
\hline & & Particulates (PM 2.5, exceedence) (-) & & 0 & 100 & 0 & Vanuatu & India & 1 \\
\hline & & Nitrogen oxides (-) & $\mathrm{g} / \mathrm{kW} \mathrm{h}$ & 2.41 & 2.99 & 0.16 & Australia & Austria & 0.20 \\
\hline \multirow[t]{7}{*}{$\begin{array}{l}\text { Environmental } \\
\text { transition }\end{array}$} & \multirow[t]{3}{*}{$\begin{array}{l}\text { Low carbon } \\
\text { transition }\end{array}$} & Share of coal based electricity in total generation (-) & $\%$ & 67.9 & 93.77 & 2.32 & $\begin{array}{l}\text { South } \\
\text { Africa }\end{array}$ & Brazil & 0.28 \\
\hline & & $\begin{array}{l}\text { Share of natural gas electricity in total electricity } \\
\text { generation }\end{array}$ & $\%$ & 10.31 & 68.31 & 0 & Thailand & $\begin{array}{l}\text { Zimbabwe and } \\
\text { several other } \\
\text { countries }\end{array}$ & 0.151 \\
\hline & & $\begin{array}{l}\text { Ratio of growth rate in natural gas electricity generation in } \\
\text { last } 5 \text { years }(2007-11) \text { to growth in electricity generation } \\
\text { in last } 5 \text { years }(2007-11)\end{array}$ & Ratio & 0.47 & 4.03 & -0.18 & China & Malaysia & 0.154 \\
\hline & \multirow[t]{4}{*}{$\begin{array}{l}\text { Zero-carbon } \\
\text { (Operation) } \\
\text { transition }\end{array}$} & $\begin{array}{l}\text { Ratio of growth rate in renewable electricity generation } \\
\text { from } 2007-11 \text { to growth in total electricity generation } \\
\text { during the same time }\end{array}$ & Ratio & 3.65 & 22.7 & 0.706 & Bulgaria & Indonesia & 0.13 \\
\hline & & $\begin{array}{l}\text { Average annual rate of growth in wind power installed } \\
\text { capacity for last } 5 \text { years }\end{array}$ & $\%$ & 20 & 80 & 2 & China & Colombia & 0.23 \\
\hline & & $\begin{array}{l}\text { Average annual rate of growth in solar power installed } \\
\text { capacity for last } 3 \text { years }\end{array}$ & $\%$ & 212 & 404 & 1 & $\begin{array}{l}\text { United } \\
\text { kingdom }\end{array}$ & South Africa & 0.52 \\
\hline & & $\begin{array}{l}\text { Average annual rate of growth in renewable power } \\
\text { installed capacity for last } 10 \text { years }\end{array}$ & $\%$ & 9.5 & 78 & 1.61 & Poland & Thailand & 0.10 \\
\hline
\end{tabular}

Table 5

Indicators of national electricity system - institutional sustainability.

\begin{tabular}{|c|c|c|c|c|c|c|c|c|c|}
\hline \multirow[t]{2}{*}{ Theme } & \multirow[t]{2}{*}{ Sub-theme } & \multirow[t]{2}{*}{ Indicator } & \multirow{2}{*}{$\begin{array}{l}\text { Units/ } \\
\text { scale }\end{array}$} & \multirow{2}{*}{$\begin{array}{l}\text { Indicator value for } \\
\text { India }\end{array}$} & \multicolumn{2}{|c|}{ Thresholds } & \multicolumn{2}{|c|}{ Threshold countries } & \multirow{2}{*}{$\begin{array}{l}\text { Normalized } \\
\text { value }\end{array}$} \\
\hline & & & & & Upper & Lower & Upper & Lower & \\
\hline \multirow{7}{*}{$\begin{array}{l}\text { Energy sector } \\
\text { governance }\end{array}$} & \multirow[t]{5}{*}{ Policy } & Availability of national energy policies & $3-1$ & 3 & 3 & 1 & & & 1 \\
\hline & & $\begin{array}{l}\text { Extent of implementation of national } \\
\text { energy policies }\end{array}$ & $3-0$ & 1 & 3 & 0 & & & 0.33 \\
\hline & & $\begin{array}{l}\text { Quality of energy planning (integrated } \\
\text { planning or sub-sector) }\end{array}$ & $3-0$ & 1 & 3 & 0 & & & 0.33 \\
\hline & & $\begin{array}{l}\text { CPIA public sector management and } \\
\text { institutions cluster average }\end{array}$ & $6-1$ & 3.6 & 4 & 2 & Georgia & $\begin{array}{l}\text { South } \\
\text { Sudan }\end{array}$ & 0.8 \\
\hline & & $\begin{array}{l}\text { Level of coordination (how decisions } \\
\text { and directions given at regional or sub } \\
\text { regional events translate into practical } \\
\text { action) }\end{array}$ & $1-0$ & 1 & 1 & 0 & & & 1 \\
\hline & \multirow[t]{2}{*}{ Institutions } & $\begin{array}{l}\text { Transparency international corruption } \\
\text { perception index }\end{array}$ & $100-0$ & 36 & 91 & 8 & Denmark & Somalia & 0.34 \\
\hline & & $\begin{array}{l}\text { Getting Electricity (Procedures required } \\
\text { to get an electricity connection; Efficacy } \\
\text { of institutions for delivery of energy } \\
\text { services; time required to get an } \\
\text { electricity connection-days) (-) }\end{array}$ & 189-1 & 111 & 189 & 1 & Bangladesh & Iceland & 0.41 \\
\hline \multirow{3}{*}{$\begin{array}{l}\text { Competition and } \\
\text { market }\end{array}$} & & Ease of doing business index $(-)$ & $189-1$ & 134 & 189 & 1 & Chad & Singapore & 0.29 \\
\hline & & Status of open access & $2-0$ & 1 & 2 & 0 & & & 0.5 \\
\hline & & Business regulatory environment & $6-0$ & 3 & 5.5 & 1.5 & Georgia & $\begin{array}{l}\text { Timor } \\
\text { Leste }\end{array}$ & 0.38 \\
\hline Finance/funding & $\begin{array}{l}\text { Financial } \\
\text { Access }\end{array}$ & $\begin{array}{l}\text { Ease of access to finance for energy } \\
\text { project financing/getting credit }(-)\end{array}$ & $189-1$ & 24 & 189 & 1 & Chad & Malaysia & 0.88 \\
\hline \multirow[t]{2}{*}{ Access to information } & & $\begin{array}{l}\text { Periodic publication of official energy } \\
\text { planning documents and/or statistics }\end{array}$ & $3-1$ & 3 & 3 & 1 & & & 1 \\
\hline & & Data coverage & $3-1$ & 2 & 3 & 1 & & & 0.5 \\
\hline
\end{tabular}

It is predominantly wind power constituting $67.88 \%$ followed by small hydro power and biomass power at $12.94 \%$ and $12.83 \%$ respectively. About $3.1 \%$ of the gross electricity generation was from renewable energy sources (excluding hydroelectricity) although the renewable electricity capacity (excluding hydro- electricity) was $8.5 \%$ of the total, in 2011 [47]. It is also important to note that benefits of the above impressive performance has not yet reached larger sections of the population. For example, more than 400 million Indians have no access to electricity [1]. 


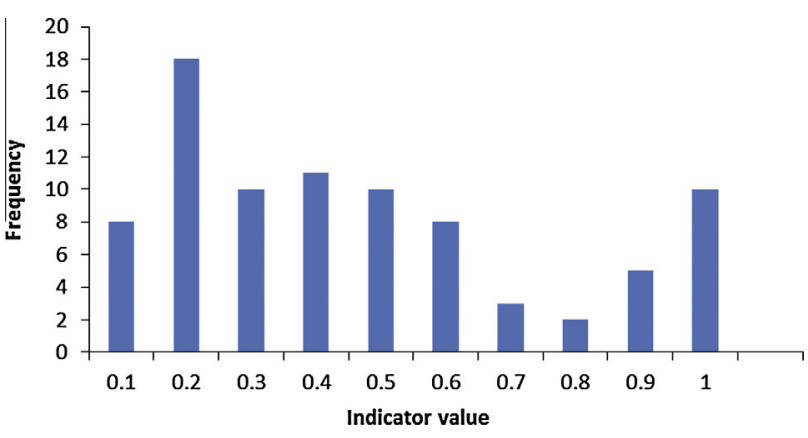

Fig. 8. Variation in normalized indicator values.

\section{Assessing national electricity system sustainability - An implementation}

The indicator framework described in the previous section has been applied to the Indian electricity system, to illustrate the application of the framework, to gain a deeper insight into the prevailing sustainability status of the national electricity system of India, and to understand the likely causes, challenges and goals, and hence possible interventions for transition toward achieving the sustainability targets.

\subsection{Quantifying indicators and assessment}

For the present study, the indicator data were gathered mainly from secondary sources of information such as journal papers, reference books, government reports, project reports, websites of concerned government departments and ministries, websites related to multilateral agencies and variety of databases from the Internet (Sustainable energy for all database, Data portal of India, Central Electricity Authority (CEA) of India, 12th five year plan document, Govt. of India, Ministry of Statistics and Program Implementation, International Energy Agency, World Bank Database, The International Renewable Energy Agency, British Petroleum). A complete list of data sources is provided in the Appendix. For data collection, owing to the availability, 2010 is taken as the ref- erence year with 2 year margin on either side to accommodate for the absence of data on some indicators for the reference year, and the availability of recent year data for some other indicators.

While attempting to quantify, benchmark and analyze the sustainability of Indian national electricity system, the indicators fell into two categories - indicators with and without data (Table 1). We claim the latter within the ambit of our extensive data search efforts.

The indicator values obtained from the secondary sources are presented in Tables 2-5. In these tables cost indicators are shown with a '-' sign in brackets. These tables from left to right, depict the hierarchy: themes, subthemes, composite indicators (where applicable) and indictors. Subsequent columns contain units of measurement, indicator values for India, threshold values followed by threshold countries, and the normalized values. There is a stark variation in the evaluated standardized indicator values (Fig. 8), ranging from permitted lower extremes of 0 as most unsustainable to 1 as most sustainable.

Aggregation of indicators according to the framework hierarchy with an associated weighing scheme to obtain the index value provides an objective measure of system performance on sustainability. Indicators contribute equally to the theme they belong to. Thematic indices so obtained contribute equally to the dimension they belong to. The dimensions contribute equally to national electricity system sustainability index (NESSI).

\subsection{Dimension-wise electricity system sustainability indices}

Here we provide a brief analysis of evaluated dimension-wise, thematic and sub-thematic sustainability indices (Table 6) developed using the underlying indicators (Tables 2-5). Simultaneously, we attempt to highlight contributions of individual indicators to these thematic indices. Table 6, from right to left depicts sub-thematic constitution of thematic indices followed by aggregation of thematic indices to yield dimensional indices. It may be observed that the institutional index, compared to other three dimensional indices, is relatively better. The constituent indicators of institutional dimension (Table 5) in contrast to indicators of other

Table 6

Thematic and sub-thematic constituents of dimensional indices.

\begin{tabular}{|c|c|c|c|c|c|}
\hline Dimension & Dimensional index & Theme & Thematic index & Sub-theme & Sub-thematic index \\
\hline \multirow[t]{7}{*}{ Social } & 0.41 & Accessibility & 0.69 & & \\
\hline & & Affordability & 0.35 & Cost & 0.63 \\
\hline & & & & Income affordability across different income groups & 0.07 \\
\hline & & Adequacy & 0.37 & Availability & 0.15 \\
\hline & & & & Constancy of supply & 0.60 \\
\hline & & Productivity & 0.26 & & \\
\hline & & Acceptability & 0.38 & & \\
\hline \multirow[t]{10}{*}{ Economic } & 0.43 & Production & 0.38 & Resource & 0.18 \\
\hline & & & & Generation & 0.56 \\
\hline & & & & Technology deployment & 0.30 \\
\hline & & & & Extent of decentralization & 0.47 \\
\hline & & Supply & 0.34 & & \\
\hline & & End use & 0.24 & Sectoral consumption & 0.40 \\
\hline & & & & Non-commercial use & 0.085 \\
\hline & & Cost & 0.79 & Technology specific cost & 0.76 \\
\hline & & Security & 0.38 & Short term reliability & 0.43 \\
\hline & & & & Long term continuity & 0.33 \\
\hline \multirow[t]{4}{*}{ Environmental } & 0.34 & Atmosphere & 0.45 & Climate change & 0.35 \\
\hline & & & & Air quality & 0.53 \\
\hline & & Environmental transition & 0.22 & Low carbon transition & 0.19 \\
\hline & & & & Zero carbon transition & 0.24 \\
\hline \multirow[t]{5}{*}{ Institutional } & 0.64 & Energy sector governance & 0.53 & Policy & 0.69 \\
\hline & & & & Institutions & 0.38 \\
\hline & & Competition and market & 0.39 & & \\
\hline & & Financing & 0.88 & & \\
\hline & & Access to information & 0.75 & & \\
\hline
\end{tabular}




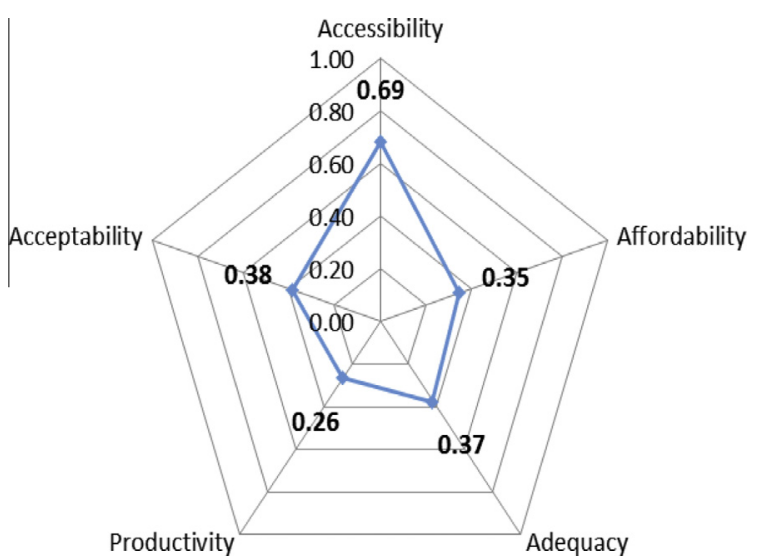

Fig. 9. Thematic indices of national electricity system - social sustainability.

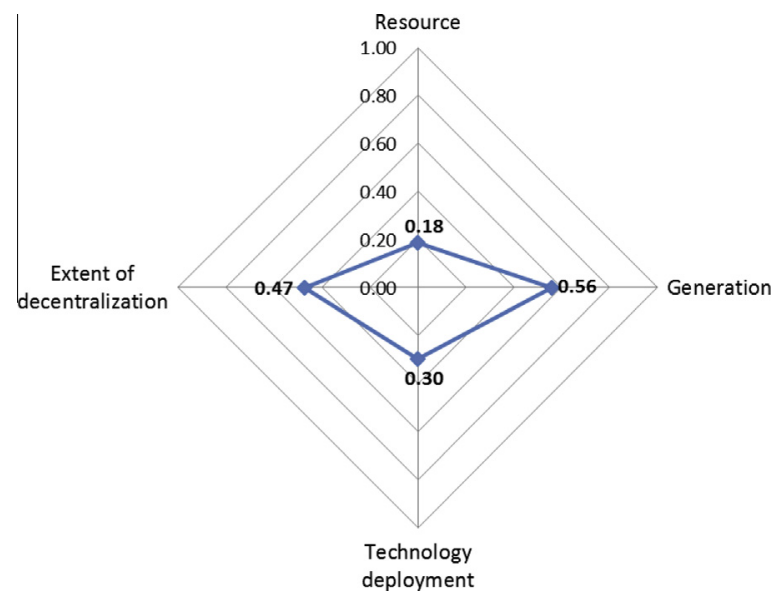

Fig. 10. Sub-thematic indices: production.

dimensions (Table 2-4) are qualitative measures and are based on stakeholder perceptions, and there could be issues of exactness and representativeness.

We may observe from Table 6 that sub-thematic indices such as affordability across different income groups, availability, resource, non-commercial use, low carbon transition and zero carbon transition appear to be the main reason for low index values for all the dimensions. For the three dimensions of sustainability, namely, social, economic and environmental, the major contributors to improving the index values are technology specific cost, constancy of supply, cost, air quality and generation at the sub-thematic level, and accessibility, cost and atmosphere at the thematic level.

\subsubsection{Social dimension}

The social dimension index value of 0.41 is relatively low compared to the ideal benchmark value of 1 . This low index value is mainly because of the relatively low values obtained for thematic dimensions on productivity, affordability, adequacy and acceptability in that order (Table 6). Further, these thematic index values have been mainly pulled down by individual indicators: cost of connection/monthly per capita expenditure (MPCE) for rural areas, cost of lifeline consumption per capita/MPCE, ratio of household electricity consumption to lifeline consumption level, average household final consumption expenditure/cost of lifeline consumption, net electricity available for supply per capita, rate of increase in electricity available for supply, economic productivity, electricity intensity in industrial sector, electricity intensity in agri-

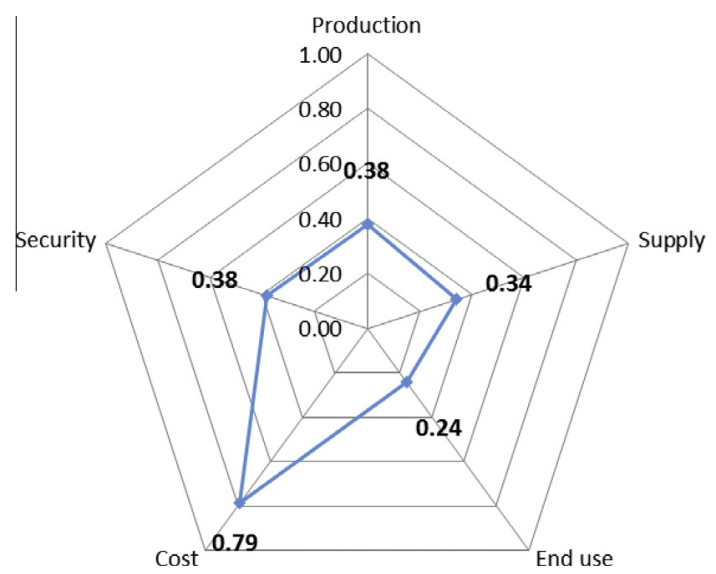

Fig. 11. Thematic indices of national electricity system - economic sustainability.

cultural sector and air pollution-PM2.6 exceedance (Table 2). Accessibility (0.69) score is highest amongst the thematic indices of social dimension (Fig. 9) largely because of higher indicator values obtained for village electrification (0.94) and urban household electricity access (0.83). However, it is moderated by relatively low values of rural household electricity access $(0.53)$ and electrification rate $(0.53 \%)$. Availability performance is low contributing to poor score for adequacy. The supply is inadequate (Adequacy $=0.37$ ) and there is an unambiguous need for supply augmentation. But demand for electricity at the price it is available is low, by and large on account of low paying capacity of electricity deprived people (Affordability $=0.35$ ). Possible solution could be opting for off-grid renewable electricity generation systems, which are more likely to employ local resources belonging to poor people while giving them access to basic and productive energy services, enabling them to enhance income levels. Leaving aside the services sector, electricity intensities in industrial sector, agricultural sector and national economy as a whole are high compared to benchmark values, and thus contributing to lower index value of productivity theme.

\subsubsection{Economic dimension}

The economic dimension index of 0.43 is low because among the constituent thematic indices, with the exception of cost all others are contributing to lowering the index value (Table 6). Fig. 10 depicts the sub-thematic indices constituting production theme, the only theme with more than two sub themes in our framework. Among the sub-thematic indices of production, resource has obtained lowest index value of 0.18 reflecting the low resource endowment and its utilization by the country. It is important to note that the low value for technology deployment is mainly caused by lack of modernization efforts, and low share of renewable energy in the Indian electricity system. India appears to be doing well with respect to sub-theme generation because it is performing relatively better in capacity expansion and its efficient utilization reflected by respective indicators (Table 3 ).

As stated above, the low relative value for economic dimension is due to lower performance with respect to most of the indicators as reflected by the values of four themes out of five (Fig. 11). The index value of supply (0.34) is low because of inefficient supply systems. Transmission and distribution losses for India (Table 3), which is the constituent of theme supply, are on the higher end of the spectrum, and only a few national electricity systems have comparable numbers. Annual household electricity consumption ( $778 \mathrm{~kW} \mathrm{~h})$ in India is low and the rate at which it is improving is also low (Table 3). This in combination with poor performance on commercial and public services and transport manifests as 


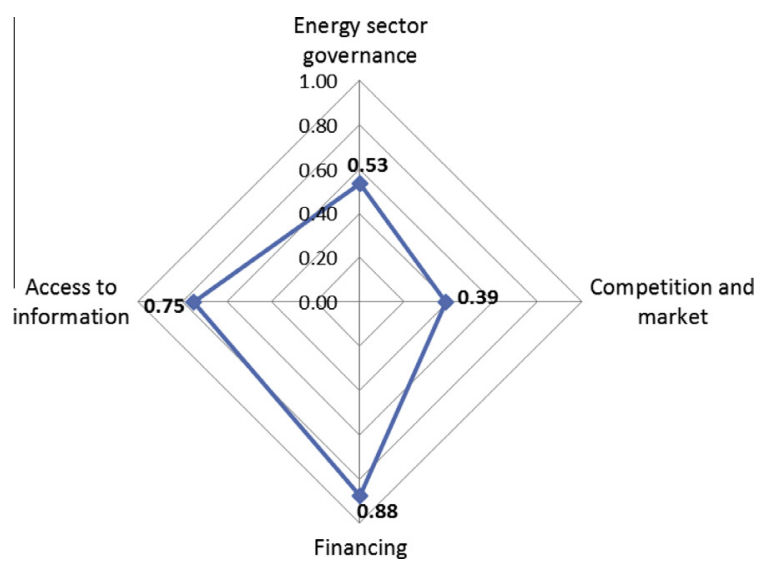

Fig. 12. Thematic indices of national electricity system - institutional sustainability.

low performance score for the theme end use (0.24). Electricity tariff in India is relatively low and affordable, partially because of the government subsidies, and this has resulted in high tariff index score (Table 3). This and the specific technology cost performance score (Table 6) are driving up the cost performance (0.79). Onshore wind electricity in terms of levelized cost of electricity is cheapest in India. This along with biomass electricity cost performance score (Table 3) are responsible for enhancing the technology cost performance.

\subsubsection{Environmental dimension}

Environmental dimension index value of 0.34 is on account of low value obtained for the thematic index environmental transition, when compared to theme atmosphere (Table 6). High $(0.83 \mathrm{~kg} / \mathrm{kW} \mathrm{h}) \mathrm{CO}_{2}$ intensity of electricity generation for India is on account of thermal dominated (66\%) electricity generation capacity. This in aggregation with low generation (2.29\%) from renewable sources contribute to the low dimensional performance. Emissions of oxides of sulfur (0.33), particulates (0.58) and nitrogen $(0.20)$, which are moderated by the generation portfolio-are also on the higher side, contributing to low environmental performance.

Zero carbon (operation) transition score (0.24), constituted by four indicators capturing deployment of renewable electricity generation capacity, is slightly better than the performance on low carbon transition (0.20). This indicates, compared to threshold countries, India is lagging behind in achieving the desired level of environmental transition. This can be observed from the low values (Table 4) obtained for indicators linked to annual growth rates of wind power and total renewable power capacity in the case of zero carbon transition. Similarly for the low carbon transition, all the three indicators contribute lowly (Table 4). Low carbon transition is measured as deployment of relatively lesser carbon emitting natural gas based generation in relation to coal based generation.

\subsubsection{Institutional dimension}

The institutional index is 0.64 , highest among the four dimensions (Table 6), because among the constituent thematic indices, with the exception of competition and market, others are relatively better (Fig. 12). Amongst the two sub-themes of policy (0.69) and institutions (0.38) constituting the theme of energy sector governance, corruption perception (Table 5) is driving the institutional index down. Low value of the theme, competition and market is driven by low scores on ease of doing business and business regulatory environment (Table 5). It means relative to other economies, India is less conducive to starting and operating a business. Status

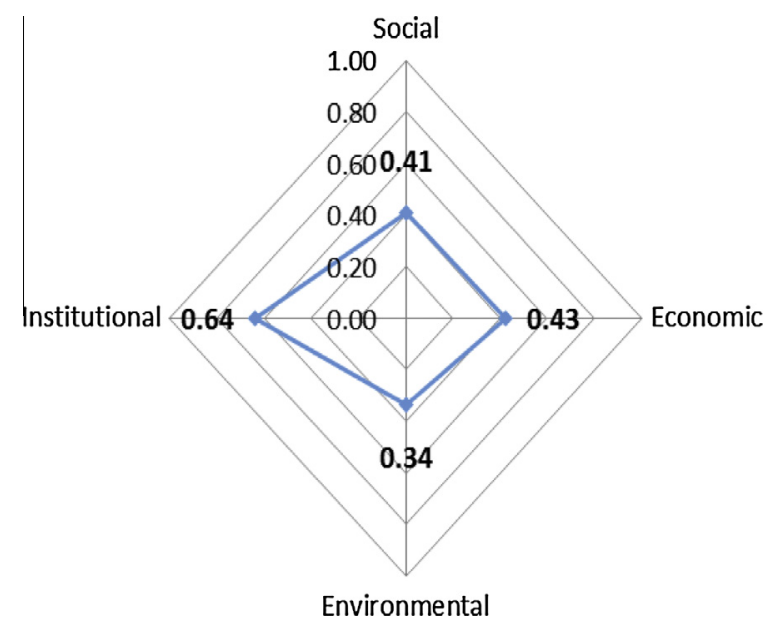

Fig. 13. Dimensional indices of national electricity system sustainability.

of open access (0.5) contributing to the theme of competition and markets is low. Effective implementation of open access is crucial for opening up consumer choices as well as encouraging a healthy trading function in the country.

Relatively high value of financing index observed through ease of getting credit as a proxy is an aggregate of metrics on credit information sharing and the legal rights of borrowers and lenders. Among the constituent indicators of theme access to information, low data coverage (Table 5) instantiated by absence of data on transmission system availability, voltage excursions (instances and duration), emissions of particulates, oxides of nitrogen and sulfur is pulling the thematic index down.

\subsection{National electricity system sustainability index (NESSI)}

Having observed a significant number of indicators across different sustainability dimensions of the electricity system as analyzed in this study as well as corroborated by the literature, we underscore that the ambit of indicators characterizing national electricity system is important. This indicates to an increasingly observable manifestation of social and environmental imperatives associated with the sustainability of national electricity system. Traditionally, emphasis has been limited to serving the economic objectives of electricity system. Widening of category definitions to address contemporary concerns and ensuing incorporation of additional indicators, which we have attempted and completed to a certain degree, and evaluating them with quantitative data, within these categories has provided a realistic assessment of electricity system performance in the Indian context.

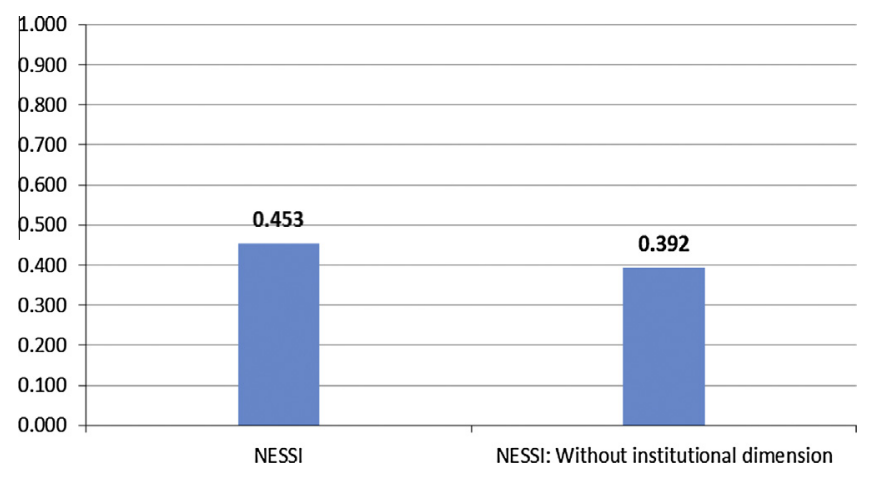

Fig. 14. NESSI with and without the institutional dimension. 
The final output of this analysis is the national electricity system sustainability index (NESSI), which we present as a single measure of sustainability of the electricity systems and can be used as a baseline target for performance improvement. The NESSI value of 0.453 is significantly lower than the ideal value of 1 . The sustainability performance, as captured with the exhaustive list of observable indicators, is low on social and environmental dimensions with a marginally better value for economic dimension (Fig. 13). The institutional dimension scores a high value of 0.64 , which as stated earlier, has a limitation of being developed from qualitative and perceptional data unlike the other three dimensions.

It is important to state here that the issue of which indicators sufficiently characterize the system, availability of pertinent data, quality of data and selection of ensuing aggregation method, has implications for the measure of overall system performance and in other words, the value of NESSI. Given the observations in Section 6.2 regarding constitution of indicators under institutional dimension and the high values associated with most of these indicators, we felt it is important to present the NESSI with and without the inclusion of institutional dimension. Fig. 14 is a plot of NESSI with and without consideration of institutional dimension. As evident (Fig. 14), institutional performance is driving the NESSI significantly up (an increase of 15\%). However, it should not have much implications for using NESSI as a target for performance improvement or as a benchmark for comparison because even for the threshold countries, the institutional dimension values have been obtained using a similar approach.

With advancements in science and technology, there are several technological options for meeting electricity needs with either more efficient use of fossil fuels or without using them at all. Owing to resource/supply constraints faced by conventional energy sources, techno-economic constraints faced by renewable energy sources and, above all, the bounds imposed by climate change on consumption of fossil fuels, there is no single silver bullet or panacea. There is no 'free lunch'. Every energy technology has serious benefits as well as costs [48]. To enhance the sustainability, India will need much more diversity in its portfolio of electricity technologies. The relationship between the indicators and the electricity system constituents and their operation is not trivial, for instance relationship between renewable energy capacity and emission reduction is nonlinear [49]. It is necessary to quantify these relationships for assessment. Further, owing to the tradeoffs amongst the desirable movement in national electricity system boundaries or indicators, e.g., generation expansion and emission reduction, the solution to the problem is not trivial. Therefore, India's success in resolving national electricity system tradeoffs remains one of the key challenges in achieving the projected development outcomes. This framework captures the tradeoffs and synergies amongst the electricity system outcomes and permits explicit consideration of decision maker preference for conflict resolution to ensure that outcomes at stakeholder level are coordinated to contribute favorably to the overall system outcome, i.e., a transition toward a sustainable national electricity system.

\section{Conclusions}

Infrastructure in general and electricity system in particular have evolved over time to supply services which societies at different points of time have considered essential for their wellbeing and for socio-economic development. This paper deals with the problem arising out of a mismatch between evolution of electricity system and the societal requirements of livability and economic development, within the purview of sustainability. A multi-hierarchical and multi-dimensional indicator approach was developed and implemented for the national electricity system of India to analyze this mismatch and quantify the sustainability gaps. The composite thematic, dimensional and overall (NESSI) index values provide the baseline measures of the sustainability performance of the Indian electricity system. The results indicate that India significantly lags behind in all three major dimensions of sustainability compared to high performing national electricity systems in the world, which have collectively contributed to the construction of hypothetical benchmarks. The NESSI value of 0.392 against a benchmark value of 1.0 is an indicator of such a low performance.

The approach and the results discussed here imply that India or any other emerging/developing country need to have a serious relook at (i) the goals and targets set for the electricity system, (ii) the set of prioritized technology and policy interventions, and (iii) the models and approaches adopted for strategic electricity planning. The results clearly indicate that countries like India need to adopt "minimizing sustainability gap" rather than "increasing GDP growth" as the sole criterion for deciding about the three challenges raised above for the electricity system. We strongly believe that this approach will not only meet the economic development objective set for the electricity system but also help achieving the societal aspirations as well as environmental compliance.

\section{Appendix A}

The data required for the analysis is dynamic, so we have cited the dynamic sources of data with a few exceptions where a specific static source like a report or document has been cited.

1. http://data.worldbank.org/data-catalog/sustainable-energyfor-all.

2. http://data.worldbank.org/.

3. http://data.gov.in/.

4. http://censusindia.gov.in/.

5. http://www.cea.nic.in/welcome1.html.

6. http://www.cea.nic.in/reports/monthly/executive_rep/ jun13.pdf.

7. http://www.cea.nic.in/reports/powersystems/nep2012/generation_12.pdf

8. http://www.cea.nic.in/reports/monthly/elec_review/jun13. pdf

9. http://www.cea.nic.in/reports/yearly/lgbr_report.pdf.

10. http://www.cea.nic.in/reports/powersystems/nep2012/generation_12.pdf.

11. http://www.cea.nic.in/reports/articles/god/letter_elect_gen_ targets_sep13.pdf.

12. http://www.cea.nic.in/reports/powersystems/large_scale_ grid_integ.pdf

13. Central electricity authority: $\mathrm{CO} 2$ baseline database.

14. http://planningcommission.gov.in/plans/planrel/12thplan/ pdf/12fyp_vol2.pdf.

15. http://mospi.nic.in/Mospi_New/site/home.aspx.

16. http://mospi.nic.in/Mospi_New/upload/dir_sample_survey_ occasn_rep_2012.pdf.

17. http://mospi.nic.in/mospi_new/upload/Energy_Statistics_ 2013.pdf?status=1\&menu_id=216.

18. http://mospi.nic.in/mospi_new/upload/Energy_stats_2014. pdf?status=1\&menu_id=229.

19. http://mospi.nic.in/mospi_new/upload/SYB2013/ch16.html.

20. http://www.iea.org/publications/freepublications/publication/ElecClimate2012_free.pdf.

21. http://www.eia.gov/cfapps/ipdbproject/IEDIndex3.cfm?tid= $2 \& \mathrm{pid}=2 \&$ aid $=12$.

22. http://stats.oecd.org/Index.aspx?DataSetCode=GREEN GROWTH. 
23. https://www.clpgroup.com/ourcompany/news/currentrelease/Documents/20121211/generatingcapacity_reservemargin_eng.pdf.

24. http://www.bp.com/en/global/corporate/about-bp/energyeconomics/statistical-review-of-world-energy-2013.html.

25. https://www.irena.org/DocumentDownloads/Publications/ Overview_Renewable\%20Power\%20Generation\%20Costs\% 20in\%202012.pdf.

26. http://www.doingbusiness.org/data/exploreeconomies/ india\#getting-electricity.

27. http://www.doingbusiness.org/data/exploreeconomies/ india.

28. http://www.indexmundi.com/.

29. http://www.doingbusiness.org/data/exploreeconomies/ india\#getting-credit.

30. http://epi.yale.

\section{References}

[1] Balachandra P. Universal and sustainable access to modern energy services in rural India: an overview of policy-programmatic interventions and implications for sustainable development. J Indian Inst Sci 2012;92(1):163-82.

[2] CensusInfo India <http://www.devinfolive.info/censusinfodashboard/website/ index.php/pages/source_lighting/total/electricity/IND>; 2011 [accessed February, 2013].

[3] IEA, International Energy Agency. Key World Energy Statistics. <http://www. iea.org/publications/freepublications/publication/KeyWorld2013.pdf>; 2013.

[4] Economic Survey. Government of India. <http://indiabudget.nic.in/ budget2012-2013/survey.asp>; 2012.

[5] Ministry of Power. Minister of State $(\mathrm{I} / \mathrm{C})$ for Power Called upon all key stakeholders in the power sector to find composite and fundamental solutions for the future needs. Press Release Ministry of Power, Government of India, New Delhi, <http://pib.nic.in/newsite/erelease.aspx> [accessed 12.02.13].

[6] Sovacool BK, Mukherjee I. Conceptualizing and measuring energy security: a synthesized approach. Energy 2011;36:5343-55.

[7] Martchamadol J, Kumar S. An aggregated energy security performance indicator. Appl Energy 2013;103:653-70.

[8] Angelis-Dimakis A, Arampatzis G, Assimacopoulos D. Monitoring the sustainability of the Greek energy system. Energy Sustain Dev 2012;16(1):51-6.

[9] Schlör H, Fischer W, Hake J. Methods of measuring sustainable development of the German energy sector. Appl Energy 2013;101:172-81.

[10] Dimitrijevic Z, Salihbegovic I. Sustainability assessment of increasing renewable energy sources penetration - JP elektroprivreda B\&H case study. Energy 2012;47(1):205-12.

[11] Vithayasrichareon P, MacGill IF, Nakawiro T. Assessing the sustainability challenges for electricity industries in ASEAN newly industrializing countries. Renew Sust Energy Rev 2012;16:2217-33.

[12] Selvakkumaran S, Limmeechokchai B. Assessment of energy security of and energy import-dependent country: a case study of Sri Lanka. Thammasat Int J Sci Technol 2012;17(1):54-67.

[13] IAEA, International Atomic Energy Agency, Vienna. Energy indicators for sustainable development: guidelines and methodologies; 2005.

[14] Ivan V, Lucille L. Energy indicators for sustainable development. Energy 2007;32(6):875-82.

[15] Jutamanee M, Kumar S. An aggregated energy security performance indicator. Appl Energy 2012;103:653-70.

[16] Weber K, Martinsen D. From system cost minimization to sustainability maximization - a new fuzzy program approach to energy systems analysis. Fuzzy Sets Syst 2013;231:1-25.

[17] Reddy AKN. Energy, environment and development: a technological perspective. Narosa Publishing House; 2006 [selected works of Prof. Amulya K.N. Reddy].

[18] Gang W, Lan-Cui L, Zhi-Yong H, Yi-Ming W. Climate protection and China's energy security: win-win or tradeoff. Appl Energy 2012;97:157-63.

[19] Dale VH, Efroymson RA, Kline KL, Langholtz MH, Leiby PN, Oladosu GA, et al. Indicators for assessing socioeconomic sustainability of bioenergy systems: a short list of practical measures. Ecol Ind 2013;26:87-102.
[20] Liao W, Heijungs R, Huppes G. Is bioethanol a sustainable energy source? An energy-, exergy-, and emergy-based thermodynamic system analysis. Renewable Energy 2011;36(12):3479-87.

[21] Sadamichi Y, Kudoh Y, Sagisaka M, Chen SS, Elauria JC, Gheewala SH, et al. Sustainability assessment methodology of biomass utilization for energy in East Asian countries. J Jpn Inst Energy 2012;91(10):960-8.

[22] Sovacool BK. Assessing energy security performance in the Asia pacific, 1990 2010. Renew Sustain Energy Rev 2013;17:228-47.

[23] Salmawy HE, Youssef K, Abdulla S, Gamea M, Hamdy K. Tracking the reliability indicators in the Egyptian electric power system. Proc MEPCON 2010:602-7.

[24] Zhou H, Chen B, Han ZX, Zhang FQ. Study on probability distribution of prices in electricity market: a case study of Zhejiang, China. Commun Nonlinear Sci Numer Simul 2009;14(5):2255-65.

[25] Zhou H, Chen B, Han ZX, Zhang FQ. Study on economic withholding in electricity market of Zhejiang Province, China. Commun Nonlinear Sci Numer Simul 2009;14(5):2495-501.

[26] OECD, Organization for Economic Cooperation and Development. OECD environmental indicators: development, measurement and use. Reference paper, Environmental Performance and Information Division, OECD, Paris; 2003.

[27] UNCHS, United Nations Center for Human Settlement. Monitoring Human Settlement with Urban Indicators, UNCHS, UN Habitat, Nairobi; 1997.

[28] UNCSD, United Nations Commission for Sustainable Development. Indicators of Sustainable Development Framework and Methodologies. Division for Sustainable Development, United Nations, New York; 1996.

[29] Sikdar SK, Sengupta D, Harten P. More on aggregating multiple indicators into a single index for sustainability analyses. Clean Technol Environ Policy 2012;14(5):765-73.

[30] Lisa S. Indicators of environment and sustainable development. The World Bank Environment Department; 2002.

[31] IISD, International Institute for Sustainable Development. Sustainable Development Indicators - Proposals for a Way Forward. IISD, Winnipeg; 2005.

[32] Agenda 21. section40.4, <http://www.un.org/earthwatch/about/docs/a21ch40. html>; 1992.

[33] Nathan Hippu SK, Reddy BS. Towards a conceptual framework for development of sustainable development indicators for an urban setup. Int J Sust Dev 2012;15(3):187-205.

[34] Poveda CA, Lipsett MG. A review of sustainability assessment and Sustainability/environmental rating systems and credit weighting tools. J Sust Dev 2011;4(6):36-55.

[35] Our common future. Report of the World Commission on Environment and Development. <http://www.un-documents.net/wced-ocf.htm>; 1987.

[36] OECD 2001b. Sustainable Development: Critical Issues. OECD, Paris; 2001.

[37] UN 2005a. 2005 World Summit Outcome. Resolution Adopted by the General Assembly. A/RES/60/1, United Nations, New York, NY, USA; 2005.

[38] IAEA, International Atomic Energy Agency, Integrated Energy Planning for Sustainable Development; Accessed in Jan; 2013.

[39] Khandker SR, Samad HA, Ali R, Barnes DF. Who benefits most from rural electrification? evidence in India. Policy Research Working Paper Series 6095, World Bank; 2012.

[40] Golumbeanu R, Barnes D. Connection charges and electricity access in SubSaharan Africa. Policy research working paper 6511, The World Bank, Africa Region, Sustainable Development Network; 2013.

[41] Page K, Evan GRD, James JD, Steven JS, Leon EC, James AE, et al. Influence of climate change mitigation technology on global demands of water for electricity generation. Int J Greenhouse Gas Control 2013;13:112-23.

[42] Kowalski K, Stagl S, Madlener R, Omann I. Sustainable energy futures: methodological challenges in combining scenarios and participatory multicriteria analysis. Eur J Oper Res 2009;197:1063-74.

[43] Afgan NH, Carvalho MG. Multi-criteria assessment of new and renewable energy power plants. Energy 2002;27:739-55.

[44] Afgan NH, Carvalho GM, Nikolai VH. Energy system assessment with sustainability indicators. Energy Policy 2000;28:603-12.

[45] MOSPI. Energy Statistics 2014, Ministry of Statistics and Programme Implementation (MOSPI), Government of India, New Delhi; 2014.

[46] CEA. Central electricity authority: $\mathrm{CO}_{2}$ baseline database; 2014.

[47] EIA, Energy Information Administration. <http://www.eia.gov/cfapps/ ipdbproject/IEDIndex3.cfm?tid=2\&pid=2\&aid=12> [accessed 12.06.14].

[48] Alley RB. Coursera: Energy, the Environment, and Our Future, <https://class. coursera.org/energy-001> [accessed in Februray 2014].

[49] Abdullah MA, Agalgaonkar AP, Muttaqi KM. Quantification of emission reduction from electricity network with the integration of renewable resources. In: Proc of IEEE power and energy Soc Gen Meet; 2011. p. 1-7. 